\title{
Schizophrenia and toxoplasmosis: association with catatonic symptoms
}

\author{
Шизофрения и токсоплазмоз: ассоциация с кататоническими симптомами \\ DOI: 10.17650/2712-7672-2020-1-1-22-29
}

\author{
Dmitry V. Romanov ${ }^{1,2}$, Alexey lu. Brazhnikov', \\ Denis S. Andreyuk ${ }^{3,4}$, Natalia V. Zakharova ${ }^{3}$, Lidia \\ V. Bravve ${ }^{3}$, Vasilisa A. Kovaleva ${ }^{5}$, Evgenia V. \\ Abbazova5, Dmitry B. Goncharov5, Irina V. Titova5, \\ Elvira A. Domonova ${ }^{5}$, George P. Kostyuk ${ }^{3}$ \\ II.M. Sechenov First Moscow State Medical University \\ (Sechenov University); ${ }^{2}$ Mental Health Research Center, \\ Moscow, Russia; ${ }^{3}$ Mental-health clinic No. 1 named after N.A. \\ Alexeev, Moscow, Russia; ${ }^{4}$ M.V. Lomonosov Moscow State \\ University, Faculty of Economics; ${ }^{5}$ N.F. Gamaleya Federal \\ Research Center for Epidemiology and Microbiology, Ministry \\ of Health of Russia.
}

\author{
Дмитрий В. Романов ${ }^{1,2}$, Алексей Ю. Бражников ${ }^{1}$, \\ Денис С. Андреюк ${ }^{3,4}$, Наталья В. Захарова3 \\ Лидия В. Бравве ${ }^{3}$, Василиса А. Ковалева \\ Евгения В. Аббазова ${ }^{5}$, Дмитрий Б. Гончаров ${ }^{5}$, \\ Ирина В. Титова5, Эльвира А. Домонова5, \\ Гоергий П. Костюк ${ }^{3}$ \\ 'Первый Московский государственный медицинский \\ университет им. И.М. Сеченова (Сеченовский \\ Университет); ${ }^{2}$ Научный центр психического здоровья, \\ Москва, Россия; ${ }^{3}$ Психиатрическая клиническая \\ больница №1 им. Н.А. Алексеева, Москва, Россия; \\ ${ }^{4}$ Московский государственный университет имени \\ М.В.Ломоносова, Экономический факультет; \\ ${ }^{5}$ Национальный исследовательский центр \\ эпидемиологии и микробиологии им. Н.Ф. Гамалеи \\ Минздрава России.
}

\section{ABSTRACT}

Introduction. The association between schizophrenia and toxoplasmosis has been demonstrated in a number of studies: the prevalence of schizophrenia is significantly higher in toxoplasmosis positive subjects than in those with T.gondii negative status. However, the clinical significance of this association remains poorly understood.

Objectives. To identify clinical phenomena that are typical for toxoplasmosis-associated (T.gondii seropositive) schizophrenia compared to Toxoplasma-seronegative schizophrenia.

Methods. A retrospective database analysis of serum samples from 105 inpatients with schizophrenia (ICD-10 code: F20; including 55 male patients; mean age of $27.4 \pm 6.4$ years) was carried out. The clinical examination involved a structured interview including ICD-10 and E. Bleuler's criteria for schizophrenia and psychometric tests (Positive and Negative Scales of PANSS). Serum antibodies (IgG) to T.gondii were identified using ELISA. The statistical significance of any differences were evaluated using the non-parametric Mann-Whitney $(U)$ and $\chi^{2}$ tests.

Results. The proportion of seropositive patients in the sample was $16.2 \%$. Comparing schizophrenia patients, who were seropositive or seronegative for toxoplasmosis, there were no statistically significant differences for the mean total PANSS score, mean PANSS-P, PANSS-N or PANSS-G scores. For the majority of PANSS items, differences were also statistically insignificant, except for G5 and G6-mannerism and posturing. Seropositive patients had a higher score for this item than seronegative patients: 3.5 versus 2.1 points $(U=389.5 ; p=0.001)$. Depression, on the contrary, was less pronounced in seropositive than seronegative patients: 1.4 versus 2.4 points $(U=509.5 ; p=0.023)$. In addition, in seropositive patients, the frequency of symptoms such as mutism according to ICD-10 criteria for schizophrenia 
was significantly higher ( $23.5 \%$ versus $3.4 \%, \chi^{2}=9.27, p=0.013$ ), and the whole group of catatonic symptoms according to the E. Bleuler's criteria for schizophrenia was higher ( $52.9 \%$ versus $28.4 \%, \chi^{2}=3.916, p=0.048$ ).

Conclusion. The association between a positive toxoplasmosis status in patients with schizophrenia and catatonic symptoms has been revealed for the first time and should be verified in larger studies.

\begin{abstract}
АННОТАЦИя
Введение. Ассоциация шизофрении и токсоплазмоза верифицирована в ряде исследований: среди инфицированных шанс диагностики шизофрении статистически значимо выше, чем при отрицательном статусе по T. gondii. При этом клиническая значимость такой связи сих пор недостаточно определена.
\end{abstract}

Цели. Выявление клинических феноменов, свойственных ассоциированной с токсоплазмозом (сероположительной) шизофрении, в сопоставлении с сероотрицательной шизофренией.

Материал и методы. Ретроспективно проанализирована база данных, составленная на основе коллекции образцов сыворотки крови 105 госпитализированных больных шизофренией (F20 по МКБ-10; 55 мужчин, средний возраст 27,4 × 6,4 года). Клиническое обследование осуществляли с применением структурированного интервью, включавшего критерии МКБ-10 и Э. Блейлера для шизофрении, а также психометрически с использованием шкалы положительных и отрицательных симптомов шизофрении (PANSS). В сыворотке крови методом иммуноферментного анализа определяли антитела класcа IgG к T. gondii. Статистическую значимость различий определяли с помощью непараметрических критериев Манна-Уитни (U) и X2.

Результаты. Доля сероположительных пациентов в выборке исследования составила 16,2\%. При сопоставлении сероположительных и сероотрицательных больных шизофренией не было обнаружено статистически значимых различий по среднему суммарному баллу шкалы PANSS и по подшкалам PANSS-P, PANSS-N, PANSS-G. По подавляющему большинству пунктов PANSS различия также оказались статистически недостоверны, за исключением пунктов G5 и G6 - манерность и поза (более высокий балл отмечен у сероположительных больных: 3,5 балла против 2,1 балла $(U=389,5 ; p=0,001))$, а также депрессии, которая, напротив, была менее выражена у сероположительных пациентов - 1,4 балла против 2,4 балла (U = 509,5; p = 0,023). Кроме того, при сероположительной шизофрении оказалась статистически значимо выше частота обнаружения такого симптома из установленных в МКБ-10 для диагностики шизофрении симптомов, как мутизм (23,5\% против 3,4\%, $\chi 2=9,27, p=0,013)$, а также всей группы кататонических симптомов по критериям шизофрении Э. Блейлера (52,9\% против 28,4\%, $\chi 2=3,916, p=0,048)$.

Выводы. Данные об ассоциации положительного статуса по токсоплазмозу у больных шизофренией с кататоническими феноменами получены впервые и требуют репликации на более крупных выборках.

Keywords: schizophrenia, toxoplasmosis, T.gondii, catatonia, Positive and Negative Syndrome Scale, PANSS. Ключевые слова: шизофрения, токсоплазмоз, T. gondii, кататония, шкала позитивных и негативных синдромов, PANSS

\section{INTRODUCTION}

A significant association between schizophrenia and toxoplasmosis caused by the neurotropic pathogen of T.gondii has been identified in a number of clinical and epidemiological studies, the results of which are illustrated, for example, in the meta-analysis by J. Gutiérrez-Fernández et al. [1]. The latter demonstrates a statistically significant correlation between the T.gondii-positive status and schizophrenia with the odds ratio (OR) of 2.50 (95\% Cl=1.40-4.47). This 
means that following T.gondii infection, the probability of schizophrenia diagnosis is 2.5 -fold higher compared to patients with T.gondii-negative status. In general, the OR ranges from 1.47 (95\% Cl=1.03-2.09) to 2.73 (95\% $\mathrm{Cl}=2.10-3.60)$ in meta-analyses and some large epidemiological studies [2-4].

Data on the prevalence of infection in patients with schizophrenia (seropositive for $\operatorname{lgG}$ ) also vary across a fairly wide range: from $16.2 \%$ to $46 \%[5,6]$.

According to a study of the Russian population of schizophrenia patients, the prevalence of the infection is as high as 40\%: 62 of 155 schizophrenia patients were seropositive for toxoplasmosis (IgG) versus 39 of 152 healthy control group subjects (25\%); the odds ratio being 1.93 [7].

The clinical significance of seropositive T.gondii status in schizophrenia patients remains poorly understood. Similarly, knowledge of the possible correlates at the symptomatic, syndromal and dimensional levels is sparse and available data largely controversial.

A comparison of Toxoplasma-seropositive patients with schizophrenia and seronegative patients has been carried out in only a few studies. F. Dickerson et al. [5] included 358 patients with schizophrenia in their study and found that seropositive patients differed significantly from seronegative patients by gender only (most patients were female, $p=0.021$ ). However, there were no significant differences in respect of age, race, level of education, age at onset, duration of schizophrenia, or for total PANSS or Repeatable Battery for the Assessment of Neuropsychological Status (RBANS) scores, smoker status, prevalence of diabetes or the use of antipsychotic drugs.

T. Çelik et al. [6] showed in a sample of 90 patients with schizophrenia that only a continuous disease course was associated with a seropositive status. No similar relationship was observed for parameters such as lack of insight or type of schizophrenia according to ICD-10 (paranoid, undifferentiated, residual, disorganized, catatonic).

A small number of scientific papers present the results of clinical and laboratory associations of toxoplasmosis in schizophrenia with individual dimensions of the mental illness. G.P. Amminger et al. [8] showed that a higher plasma level of IgG was significantly associated with a greater severity of positive symptoms on the Brief Psychiatric Rating Scale (BPRS) in a group of patients with an ultra-high risk of psychosis (attenuated or short-term psychotic symptoms).

In a study by D. Holub et al. [9], seropositive schizophrenia patients demonstrated statistically significant differences in the severity of symptoms ( $p=0.032)$ assessed using the PANSS-P (Positive Symptoms Subscale) but not PANSS-N (Negative Symptoms Subcale) or General Psychopathology PANSS-G subscale, when compared to seronegative subjects. The authors noted that the onset of schizophrenia in infected male patients occurred approximately a year earlier than in non-infected males while in infected female patients it was three years later than in non-infected female patients. In addition, the last hospital stay at the time of the study was, on average, 33 days longer than in the case of seropositive schizophrenia patients than in seronegative patients $(p=0.003)$.

Comparable data were obtained in one of the largest studies on the association between schizophrenia and toxoplasmosis, which included 600 patients with the first episode of schizophrenia [10]. The authors showed that there were no significant differences between the groups in terms of parameters such as gender, age, level of education, disease duration, age at the time of schizophrenia onset, living conditions (urban, rural) or family history of mental illness. They also demonstrated that schizophrenia patients with chronic toxoplasmosis had a higher PANSS Positive Subcale score (mean PANSS-P score: 20.8 versus 19.4), cognitive symptoms score (mean score: 8.5 versus 7.7 ) and excitement score (mean score: 9.5 versus 7.9 ) and a significantly lower PANSS Negative Subcale Score (mean PANSS-N score: 16.4 versus 17.8) compared to seronegative patients. However, none of the above publications provides an analysis of differences in individual PANSS scale items or schizophrenia symptoms.

Therefore, the goal of the study was to identify clinical phenomena that are typical for toxoplasmosis-associated (T.gondii seropositive) schizophrenia compared to seronegative schizophrenia.

\section{MATERIALS AND METHODS}

Study Design A retrospective database analysis of serum samples obtained from schizophrenia patients was carried out. The patients were included in the databases as part of the research programme "International approaches to studying human and society mental health" conducted in the Mental-health clinic No. 1, named after N.A. Alexeev 
since 2017. The study was approved by the independent interdisciplinary ethics committee of clinical studies on 14th July, 2017 (meeting minutes No. 12). Serum samples obtained from schizophrenia patients were collected from January 2019 to February 2020.

Inclusion Criteria included schizophrenia diagnosis according to the ICD-10 criteria (F20); age $>18$ years and signature on the informed consent form for both participation in the study and testing of biological samples (blood serum).

Exclusion Criteria included structural CNS disorders (F0) according to the ICD-10 criteria, psychoactive substance dependence (F1), affective psychoses (F3) according to the ICD-10 criteria and exacerbations of autoimmune disorders that could potentially distort the results of serology testing.

Clinical examination of patients was carried out in the first days of their hospital stay by two psychiatrists using a single structured interview and also collecting social, demographic and certain clinical symptoms of schizophrenia. The interview included the criteria for schizophrenia diagnosis according to the ICD-10 (important symptoms, some of which are observed during most of an episode lasting one month or longer) supplemented by E. Bleuler's criteria [11] and a psychometric evaluation of symptoms using the PANSS scale $[12,13]$.

Blood sampling was performed once from the cubital vein in the morning under fasting conditions between 8.00 and $8.30 \mathrm{am}$. Blood samples were placed in test tubes with ethylenediaminetetraacetic acid (EDTA) and transported to the laboratory within two hours to material safety requirements. Blood was centrifuged at $750 \mathrm{~g}$ for $15 \mathrm{~min}$ at $22^{\circ} \mathrm{C}$; plasma was collected and subsequently used for testing. Frozen samples were stored at $-18^{\circ}$ to $-24^{\circ} \mathrm{C}$.
Serology Testing Methods. Serum levels of anti- $T$. gondii antibodies (IgG) were determined in the blood samples using ELISA and a ToxaplaStripg kit (Certificate 9398-005-4037-1634-2008).

Statistical Analysis Methods. Differences in quantitative ordinal variables (mean total PANSS scores, PANSS-P score, PANSS-N score, PANSS-G score, as well as individual PANSS items) were evaluated using the MannWhitney test (U). The nonparametric chi-squared test $\left(X^{2}\right)$ was used to compare the frequencies of categorical variables (individual symptoms of schizophrenia according to the ICD-10 and the E. Bleuler's criteria [11]). The level of statistical significance was 0.05 .

Sample Characteristics. The study included 105 patients with schizophrenia (including 55 and 50 male and female patients, respectively). The mean age was $27.4 \pm 6.4$ years (ranging from 18 to 50 years) with a median age of 27 years. The age of the prodromal symptoms onset was $19.1 \pm 7.4$ years and the age at schizophrenia onset was $23.9 \pm 7.2$ years. The disease durations from the beginning of the prodromal symptoms onset and from the onset of the active phase were $8.6 \pm 7.1$ years and $3.7 \pm 4.6$ years, respectively.

\section{RESULTS}

The proportion of seropositive patients in the sample was $16.2 \%$ (17 out of 105 cases). When comparing Toxoplasma-seropositive or seronegative schizophrenia patients, no statistically significant differences were found in parameters such as the mean total PANSS score, mean PANSS-P, PANSS-N or PANSS-G scores, although there was a general trend towards a higher mean total score for all subscales and the total PANSS score among patients who were seropositive (Table 1).

Table 1. Results of comparison of PANSS items in schizophrenia patients depending on their seropositive (Ig+) or seronegative (Ig-) status (M \pm SD)

\begin{tabular}{|l|l|l|l|l|}
\hline Item & $\begin{array}{l}\text { Ig+ } \\
(\mathbf{n = 1 7})\end{array}$ & $\begin{array}{l}\text { Ig- } \\
(\mathbf{n = 8 8})\end{array}$ & $\mathbf{U}$ \\
\hline Mean PANSS total score $(\Sigma)$ & $103.7 \pm 23.8$ & $96.0 \pm 28.6$ & 735.0 & 0.266 \\
\hline Mean PANSS-P (Positive Scale) Score & $26.4 \pm 6.1$ & $23.8 \pm 8.4$ & 881.0 & 0.182 \\
\hline Mean PANSS-N (Negative Scale) score & $28.2 \pm 9.4$ & $24.9 \pm 9.8$ & 837.5 & 0.262 \\
\hline Mean PANSS-G (General Psychopathology Scale) Score & $49.3 \pm 11.7$ & $47.0 \pm 13.2$ & 739.5 & 0.525 \\
\hline
\end{tabular}


For the majority of PANSS items, differences were also statistically insignificant, except for two items on the PANSS-G scale-G5 and G6 (Table 2). The total score for "G5. Mannerisms and posturing item" in seropositive patients was statistically significantly higher at 3.5 points versus 2.1 points $(p=0.002)$ and "G6. Depression" total score in seropositive patients was statistically significantly lower at 1.4 points versus $2.4(p=0.025)$.

Given the statistical difference for the item G5 (mannerisms and posturing), an additional analysis of clinical data was conducted. The differences between the groups of seropositive and seronegative patients were analysed by categorical variables, which also included descriptions of motor phenomena observed in schizophrenia (primarily catatonia). In accordance with the ICD-10 criteria for schizophrenia, seropositive patients demonstrated a statistically significantly higher rate of mutism (23.5\% versus 3.4\%, $\chi 2=9.27, p=0.013$ ). However, the frequency of other ICD-10 defined catatonic symptoms was similar in both groups. Based on E. Bleuler's criteria (1911) [11], a statistically significant difference was observed for all catatonic symptoms (52.9\% versus $\left.28.4 \%, \chi^{2}=3.916, p=0.048\right)$.

\section{DISCUSSION}

The proportion of seropositive patients in the sample of schizophrenia patients established in this study (16.2\%) is consistent with the lower values of the range given in the literature of $16.2-46 \%[5,10]$ and considerably lower than that obtained in one of the Russian studies, also carried out on the population of patients with schizophrenia in the Moscow region (40\%) [7]. This may be partly due to the younger age of patients in this study (mean and median values are 27 years); many were undergoing diagnostic evaluation for their first psychotic episode.

Comparing Toxoplasma-seropositive and seronegative schizophrenia patients, no statistically significant differences were found in parameters such as the mean total PANSS score, mean PANSS-P, PANSS-N or PANSS-G scores. In this respect, our data are consistent with the results obtained by F. Dickerson et al. [5] who did not reveal any differences in the total PANSS score and by D. Holub et al. [9] who also found no differences in the PANSS-N or PANSS-G scores. However, D. Holub et al. [9] and H.L. Wang et al. [10] showed a higher PANSS-P in seropositive patients, which differs from our findings. In our study, although the total PANSS-P scores were higher in seropositive patients, the differences did not reach statistical significance. Moreover, in the study by H.L. Wang et al. [10], seropositive patients were found to have significantly lower PANSS-N scores, which was not observed in our study or by other authors $[5,9]$.

None of the studies showed data on individual PANSS items, which could underlie the differences in question and none of them demonstrated data on individual schizophrenia symptoms assessed using other methods.

The statistically significant differences in respect of the G5 item "Mannerisms and posturing" observed in our study indicate that seropositive patients had more severe catatonic motor symptoms (clumsiness, unnatural movements, discoordination, bizarre and fixed postures, stiffening, habits and stereotypes), which were registered according to the PANSS instructions by physicians who were observing patients during the interview (or based on information obtained from personnel or relatives) $[12,13]$. The data indicating the association of toxoplasmosis seropositive status and catatonic symptoms were supported by the evidence that seropositive patients were statistically significantly more likely to have mutism (according to the ICD-10 criteria) and all groups of catatonic symptoms according to E. Bleuler's criteria [11].

This association of seropositive toxoplasmosis status and catatonic phenomena in schizophrenia patients may be due to a mild neurological deficit that develops as a result of the neutropic effect of the infection and mimics and/or amplifies motor symptoms associated with schizophrenia. It should be noted that this assumption is consistent with the modern concept of catatonia in the Diagnostic and Statistical Manual of Mental Disorders (DSM-5) and International Classification of Diseases 11 th Revision (ICD-11) as a syndrome, which can be seen in a wide range of diseases, both those of the schizophrenic spectrum and organic CNS disorders.

Some studies of organic psychoses in patients with Toxoplasma infection, both congenital and acquired, can be considered as clinical observations indirectly confirming this hypothesis $[14,15]$. The aforementioned studies provide psychopathological characteristics of schizophreniform disorders associated with toxoplasmosis. Some of them are classified as oneiroidcatatonic conditions (delusional interpretation oneiroids) with mild cloudiness of consciousness. According to the authors, these psychoses could 
Table 2. Comparison of mean PANSS scores depending on seropositive (Ig+) or seronegative (Ig-) status of patients $(M \pm S D)$

\begin{tabular}{|c|c|c|c|c|}
\hline Items & $\begin{array}{l}\text { IgG+ }(n=17), \\
\text { Mean score }\end{array}$ & $\begin{array}{l}\text { IgG- }(\mathrm{n}=88) \text {, } \\
\text { Mean score }\end{array}$ & $\mathbf{U}$ & $\mathbf{p}$ \\
\hline P1. Delusions & $5.41 \pm 1.50$ & $4.52 \pm 1.89$ & 540.50 & 0.064 \\
\hline P2. Conceptual disorganization & $4.71 \pm 1.40$ & $3.95 \pm 1.71$ & 564.00 & 0.116 \\
\hline P3. Hallucinatory behaviour & $3.24 \pm 2.49$ & $3.28 \pm 2.23$ & 723.00 & 0.820 \\
\hline P4. Excitement & $3.12 \pm 1.76$ & $2.75 \pm 1.67$ & 655.00 & 0.403 \\
\hline P5. Grandiosity & $2.53 \pm 1.55$ & $2.45 \pm 1.81$ & 704.50 & 0.683 \\
\hline P6. Suspiciousness/persecution & $4.59 \pm 1.23$ & $4.11 \pm 1.38$ & 583.50 & 0.160 \\
\hline P7. Hostility & $2.76 \pm 1.60$ & $2.60 \pm 1.81$ & 697.00 & 0.642 \\
\hline N1. Blunted affect & $4.06 \pm 1.68$ & $3.63 \pm 1.67$ & 651.00 & 0.386 \\
\hline N2. Emotional withdrawal & $4.29 \pm 1.40$ & $3.60 \pm 1.52$ & 549.00 & 0.087 \\
\hline N3. Poor rapport & $3.88 \pm 1.45$ & $3.20 \pm 1.63$ & 585.00 & 0.164 \\
\hline N4. Passive/apathetic social withdrawal & $3.94 \pm 1.68$ & $3.84 \pm 1.60$ & 721.50 & 0.813 \\
\hline N5. Difficulty in abstract thinking & $4.29 \pm 1.57$ & $3.57 \pm 1.64$ & 561.50 & 0.111 \\
\hline N6. Lack of spontaneity and flow of conversation & $3.71 \pm 1.72$ & $3.50 \pm 1.71$ & 694.50 & 0.637 \\
\hline N7. Stereotyped thinking & $4.00 \pm 1.54$ & $3.53 \pm 1.72$ & 618.50 & 0.278 \\
\hline G1. Somatic concern & $2.06 \pm 1.56$ & $1.90 \pm 1.40$ & 695.00 & 0.601 \\
\hline G2. Anxiety & $3.18 \pm 1.24$ & $3.28 \pm 1.38$ & 674.50 & 0.507 \\
\hline G3. Guilt feelings & $1.53 \pm 1.33$ & $1.66 \pm 1.29$ & 691.00 & 0.513 \\
\hline G4. Tension & $2.76 \pm 1.30$ & $3.09 \pm 1.46$ & 650.50 & 0.382 \\
\hline G5. Mannerisms and posturing & $3.53 \pm 1.74$ & $2.11 \pm 1.68$ & 389.50 & 0.001 \\
\hline G6. Depression & $1.41 \pm 0.94$ & $2.41 \pm 1.76$ & 509.50 & 0.023 \\
\hline G7. Motor retardation & $2.35 \pm 1.62$ & $1.94 \pm 1.46$ & 644.50 & 0.305 \\
\hline G8. Uncooperativeness & $2.71 \pm 1.69$ & $2.60 \pm 1.65$ & 729.00 & 0.863 \\
\hline G9. Unusual thought content & $4.00 \pm 1.17$ & $3.48 \pm 1.39$ & 593.00 & 0.164 \\
\hline G10. Disorientation & $1.88 \pm 1.17$ & $1.65 \pm 1.05$ & 671.50 & 0.434 \\
\hline G11. Poor attention & $4.18 \pm 1.63$ & $3.61 \pm 1.64$ & 593.00 & 0.191 \\
\hline G12. Lack of judgement and insight & $4.88 \pm 1.65$ & $4.37 \pm 1.71$ & 606.50 & 0.234 \\
\hline G13. Disturbance of volition & $4.31 \pm 1.25$ & $3.74 \pm 1.55$ & 561.00 & 0.184 \\
\hline G14. Poor impulse control & $2.88 \pm 1.69$ & $2.91 \pm 1.71$ & 745.50 & 0.982 \\
\hline G15. Preoccupation & $4.47 \pm 1.46$ & $4.06 \pm 1.65$ & 630.00 & 0.294 \\
\hline G16. Active social avoidance & $4.00 \pm 1.37$ & $3.94 \pm 1.50$ & 726.50 & 0.848 \\
\hline
\end{tabular}


be initially considered hallucinatory-paranoid states [15] with a phenomenon of psychic automatism and a delusional misidentification syndrome or Capgras delusion, as well as religious or love delusions [14]. More severe disorders of consciousness in such patients were associated with catatonic symptoms (substupor or stereotypic arousal). However, in some cases the investigators also observed (as the disorders of consciousness became less pronounced) the phenomenon of a lucid catatonia syndrome. The investigators noted that gradually progressive toxoplasmosis was associated with alterations of exacerbations in the form of substupor states and psychomotor excitement, which was the reason why some patients were initially diagnosed with catatonic schizophrenia [14].

Some hypotheses suggested by other authors may be considered biological grounds that are consistent with our working hypothesis [10, 16-18]. Thus, the heterogeneity of psychopathological and neurological symptoms associated with Toxoplasma invasion may be associated with patterns of distribution of parasite cysts in the host brain. Predominant topical localization of cysts in dopaminergic structures in some cases might cause the development of schizophrenic symptoms or amplification of certain schizophrenic phenomena, e.g., catatonic manifestations, which are considered as a transnosological construct in modern research. Some authors believe that the mechanism underlying this association may be due to the ability of T.gondii to increase dopaminergic activity $[19,20]$ or its effects on tryptophan metabolism in the corresponding structures [21], which requires verification in further morphological and neuroimaging studies.

The discussion of the association between depressionrelated symptoms in seropositive patients is beyond the scope of this article. However, we may stipulate that this is consistent with the findings of a clinical and epidemiological study by A.B. Smulevich et al. [22] who investigated the association of depressive and other schizophrenia symptoms and demonstrated a negative correlation between the rate of depressive and catatonic symptoms.

\section{CONCLUSION}

Our results may be relevant for further research on the nature of the association of seropositive toxoplasmosis status with clinical manifestations of schizophrenia and its underlying mechanisms.

Given the inconsistency of available published data regarding the association of toxoplasmosis seropositive status with individual dimensions on the PANSS scale (primarily positive and negative items), it is probably too early to draw unambiguous conclusions about this relationship. Future research in larger samples and/ or a meta-analysis of available publications is needed.

However, we have not been able to find information on the association of seropositive status with catatonic symptoms in schizophrenia in the available publications and it is probably discussed for the first time, which determines the novelty of this study. Our data on the association with catatonic symptoms need to be replicated and further confirmed using biological methods, taking into account the clinical characteristics of schizophrenia. The obtained data can be used for differential diagnosis of endogenous and organic psychoses and therefore, for differential treatment approaches taking into account the possible role of toxoplasmosis in schizophrenia, as well as its potentially modifying effects on the clinical manifestations of schizophrenia.

Author Contributions: Dmitry V. Romanov, Alexey Yu. Brazhnikov, George P. Kostyuk, Denis S. Andreyuk, Dmitry B. Goncharov: development and approval of the study design; Denis S. Andreyuk, Natalia V. Zakharova, Lidia V. Bravve: obtaining clinical data for analysis, preliminary analysis of the obtained clinical data; Vasilisa A. Kovaleva, Evgenia V. Abbazova, Dmitry B. Goncharov, Irina V. Titova, Elvira A. Domonova: obtaining immunological data for analysis, preliminary analysis of the obtained immunological data; Alexey Yu. Brazhnikov, Dmitry V. Romanov: statistical data analysis, summary and final analysis of the obtained data; Dmitry V. Romanov, Dmitry B. Goncharov: writing the text of the manuscript; Vasilisa A. Kovaleva, DmitryV. Romanov: review of publications relevant to the article.

Funding: The study was conducted without the sponsor's support.

Conflict of Interest: The authors declare no conflicts of interest.

Informed Consent: All patients signed the informed consent form for participation in the study and testing of biological samples. 


\section{Correspondence to:}

\section{Dmitry V. Romanov}

dm.v.romanov@mail.ru

\section{References}

1. Gutiérrez-Fernández J, Luna Del Castillo Jde D, Mañanes-González S, Carrillo-Ávila JA, Gutiérrez B, Cervilla JA, Sorlózano-Puerto A. Different presence of Chlamydia pneumoniae, herpes simplex virus type 1 , human herpes virus 6 , and Toxoplasma gondii in schizophrenia: meta-analysis and analytical study. Neuropsychiatr Dis Treat. 2015 Mar 27;11:843-52. doi: 10.2147/NDT.S79285. PMID: 25848282; PMCID: PMC4384747.

2. Burgdorf KS, Trabjerg BB, Pedersen MG, Nissen J, Banasik K, Pedersen OB, Sørensen E, Nielsen KR, Larsen MH, Erikstrup C, Bruun-Rasmussen P, Westergaard D, Thørner LW, Hjalgrim H, Paarup HM, Brunak S, Pedersen CB, Torrey EF, Werge T, Mortensen PB, Yolken RH, Ullum H. Large-scale study of Toxoplasma and Cytomegalovirus shows an association between infection and serious psychiatric disorders. Brain Behav Immun. 2019 Jul;79:152-158. doi: 10.1016/j.bbi.2019.01.026. Epub 2019 Jan 29. PMID: 30685531.

3. Torrey EF, Bartko JJ, Lun ZR, Yolken RH. Antibodies to Toxoplasma gondii in patients with schizophrenia: a meta-analysis. Schizophr Bull. 2007 May;33(3):729-36. doi: 10.1093/schbul/sbl050. Epub 2006 Nov 3. PMID: 17085743 ; PMCID: PMC2526143.

4. Torrey EF, Bartko JJ, Yolken RH. Toxoplasma gondii and other risk factors for schizophrenia: an update. Schizophr Bull. 2012 May;38(3):642-7. doi: 10.1093/schbul/sbs043. Epub 2012 Mar 23. PMID: 22446566; PMCID: PMC3329973.

5. Dickerson F, Boronow J, Stallings C, Origoni A, Yolken R. Toxoplasma gondii in individuals with schizophrenia: association with clinical and demographic factors and with mortality. Schizophr Bull. 2007 May;33(3):737-40. doi: 10.1093/ schbul/sbm005. Epub 2007 Feb 20. PMID: 17314085; PMCID: PMC2526149.

6. Celik T, Kartalci S, Aytas O, Akarsu GA, Gozukara H, Unal S. Association between latent toxoplasmosis and clinical course of schizophrenia - continuous course of the disease is characteristic for Toxoplasma gondii-infected patients. Folia Parasitol (Praha). 2015 Jan 1;62:2015.015. doi: 10.14411/fp.2015.015. PMID: 25960559.

7. Stepanova EV, Kondrashin AV, Sergiev VP, Morozova LF, Turbabina NA, Maksimova MS, Romanov DV, Kinkulkina MA, Lazareva AV, Morozov EN. Toxoplasmosis and mental disorders in the Russian Federation (with special reference to schizophrenia). PLoS One. 2019 Jul 10;14(7):e0219454. doi: 10.1371/journal.pone.0219454. PMID: 31291336; PMCID: PMC6636601.

8. Amminger GP, McGorry PD, Berger GE, Wade D, Yung AR, Phillips LJ, Harrigan SM, Francey SM, Yolken RH. Antibodies to infectious agents in individuals at ultra-high risk for psychosis. Biol Psychiatry. 2007 May 15;61(10):1215-7. doi: 10.1016/j. biopsych.2006.09.034. Epub 2007 Jan 3. PMID: 17207471.

9. Holub D, Flegr J, Dragomirecká E, Rodriguez M, Preiss M, Novák T, Čermák J, Horáček J, Kodym P, Libiger J, Höschl C, Motlová LB. Differences in onset of disease and severity of psychopathology between toxoplasmosis-related and toxoplasmosis-unrelated schizophrenia. Acta Psychiatr Scand. 2013 Mar;127(3):227-38. doi: 10.1111/acps.12031. Epub 2012 Nov 5. PMID: 23126494.

10. Wang HL, Wang GH, Li QY, et al. Prevalence of Toxoplasma infection in first-episode schizophrenia and comparison between
Toxoplasma-seropositive and Toxoplasma-seronegative schizophrenia. Acta Psychiatrica Scandinavica. 2006 Jul;114(1):4048. DOI: $10.1111 /$ j.1600-0447.2006.00780.x.

11. Bleuler E. Dementia praecox oder Gruppe der Schizophrenien. Handbuch der Psychiatrie (Herausgeb. von G. Aschaffenburg). Spezieller Teil. 4. Abteilung, 1. Haelfte. Leipzig und Wien: Franz Deuticke; 1911.

12. Kay SR, Opler LA, Lindenmayer JP. The Positive and Negative Syndrome Scale (PANSS): rationale and standardisation. Br J Psychiatry Suppl. 1989 Nov;(7):59-67. PMID: 2619982.

13. Mosolov SN. Shkaly psihometricheskoj ocenki simptomatiki shizofrenii i koncepcija pozitivnyh i negativnyh rasstrojstv [Scales for psychometric evaluation of symptoms in schizophrenia and the concept of positive and negative disorders]. Moscow: Moscow; 2001. 238 p. Russian.

14. KliuevaTD,SamobumskaiaEN,TikhovskaiaTM.Psikhozypri toksoplazmoze[Psychosesintoxoplasmosis].ZhNevropatol Psikhiatr ImS SKorsakova.1966;66(3):454-8. Russian.PMID:6000444.

15. Mikhalev PV, Genailo SP, Mikhaleva LV. Ob oneiroidnykh i oniricheskikh sostoianiiakh pri tserebral'nom toksoplazmoze [Oneiroid and oneiric states in cerebral toxoplasmosis]. Zh Nevropatol Psikhiatr Im SS Korsakova. 1978;78(2):251-5. Russian. PMID: 636721.

16. Holub D, Flegr J, Dragomirecká E, Rodriguez M, Preiss M, Novák T, Čermák J, Horáček J, Kodym P, Libiger J, Höschl C, Motlová LB. Differences in onset of disease and severity of psychopathology between toxoplasmosis-related and toxoplasmosis-unrelated schizophrenia. Acta Psychiatr Scand. 2013 Mar;127(3):227-38. doi: 10.1111/acps.12031. Epub 2012 Nov 5. PMID: 23126494.

17. Esshili A, Thabet S, Jemli A, Trifa F, Mechri A, Zaafrane F, Gaha L, Juckel G, Babba H, Bel HadjJrad B. Toxoplasma gondii infection in schizophrenia and associated clinical features. Psychiatry Res. 2016 Nov 30;245:327332. doi: 10.1016/j.psychres.2016.08.056. Epub 2016 Aug 22. PMID: 27573055.

18. HoracekJ,FlegrJ,TinteraJ,VerebovaK,SpanielF,NovakT,Brunovsky M,Bubenikova-ValesovaV,HolubD,PalenicekT,HöschlC.Latent toxoplasmosisreducesgraymatterdensityinschizophreniabutnotin controls:voxel-based-morphometry(VBM)study.WorldjBiol Psychiatry. 2012Oct;13(7):501-9.doi:10.3109/15622975.2011.573809.Epub2011 May 23.PMID:21599563.

19. Flegr J, Preiss M, Klose J, Havlícek J, Vitáková M, Kodym P. Decreased level of psychobiological factor novelty seeking and lower intelligence in men latently infected with the protozoan parasite Toxoplasma gondii Dopamine, a missing link between schizophrenia and toxoplasmosis? Biol Psychol. 2003 Jul;63(3):253-68. doi: 10.1016/s0301-0511(03)000759. PMID: 12853170.

20. Gaskell EA, Smith JE, PinneyJW, Westhead DR, McConkey GA. A unique dual activity amino acid hydroxylase in Toxoplasma gondii. PLoS One. 2009;4(3):e4801. doi: 10.1371/journal.pone.0004801. Epub 2009 Mar 11. PMID: $19277211 ;$ PMCID: PMC2653193.

21. Schwarcz R, Hunter CA. Toxoplasma gondii and schizophrenia: linkage through astrocyte-derived kynurenic acid? Schizophr Bull. 2007 May;33(3):652-3. doi: 10.1093/schbul/sbm030. Epub 2007 Apr 13. PMID: 17434932; PMCID: PMC2526138.

22. Smulevich AB, Briko NI, Andryushchenko AV, Romanov DV, Shuliak YA, Brazhnikov AY, Gerasimov AN, Melik-Pashaian AE, Mironova EV, Pushkarev DF. Komorbidnost' depressii i rasstroistv neaffektivnogo shizofrenicheskogo spektra: kliniko-epidemiologicheskoe issledovanie EDIP [Comorbidity of depression and nonaffective - schizophrenia spectrum disorders: the clinical-epidemiological study EDIP]. Zh Nevrol Psikhiatr Im S S Korsakova. 2015;115(11 Pt 2):6-19. Russian. doi: 10.17116/jnevro20151151126-19. PMID: 26978259. 